\title{
An Analysis on the Satisfaction and Perception of Performance Outcomes of the University Information Disclosure System
}

\author{
Ho-Seub Lee ${ }^{1}$, Suk-Yeol Lee ${ }^{2}$ and Jai-Young Shin ${ }^{3}$ \\ ${ }^{1}$ Professor, Division of General Education, Namseoul University, Cheonan, Korea \\ ${ }^{2}$ Professor, Division of General Education, Sookmyung Women's University, \\ Seoul, Korea \\ ${ }^{3}$ Department head, Office of Planning and Budget, Chung-Ang University, \\ Seoul, Korea \\ Ileesy@nsu.ac.krmail, 22smlhs@sookmyung.ac.kr, 3jyshin@cua.ac.kr
}

\begin{abstract}
The purpose of this study is to analyze the satisfaction and perception of performance outcomes of the university information disclosure system. This is to examine whether the university information disclosure system provides users with customized information and if it satisfies the public's right to know. To this end, this study surveyed a group of active users of the university information disclosure system (high school teachers, university professors, and university administrators) regarding the purpose of use, satisfaction, and perception of its performance. The survey analysis results show the highest-ranking purpose of use was to acquire various information about the university and to acquire information necessary for university research and evaluation. The overall satisfaction with the university information disclosure system is generally high. Upon analyzing satisfaction according to the purpose of use, the performance perception of the university information disclosure system was also high. However, the satisfaction of users with college admission information is relatively low. Also, compared to other outcomes, satisfaction in providing an opportunity for university selection was the lowest. The approach to enhance the enterprise agility of the university information disclosure system in the future needs to meet the information demands of two major groups. It is necessary to establish and implement a strategy that can meet the information needs on university admissions, of whom teachers are representative, and the information demands of consumers who need to select a university.
\end{abstract}

Keywords: University information disclosure system, Satisfaction, Information needs, Purpose of use, Perception of performance outcome

\section{Introduction}

The demand for quality and accountability in higher education is increasing in South Korea, with greater emphasis on the transparency of university management [1][2]. One of the important mechanisms for change was the implementation of the university information disclosure system. According to current law, all four-year universities in Korea are required to disclose various wide-ranging information on education, research, social services,

Article history:

Received (September 12, 2020), Review Result (October 17, 2020), Accepted (November 20, 2020)

Print ISSN: 2207-5380, eISSN: 2207-290X AJEMR

Copyright (C) 2020 Global Vision Press (GV Press) 
accounting records, human resources, administration, facilities, etc. The institutions are required to disclose and update this information on the university's homepage and related websites every year. The purpose of the university information disclosure system is to provide tailored and accurate information for students, parents, businesses, and the government [3][4].

After the university information disclosure was implemented, various studies were conducted to understand the outcomes and effects of this project and to seek improvement measures. Numerous studies investigated user satisfaction and sought improvement plans based on the results. However, these studies were limited as they did not address how the system's ultimate goal was achieved, nor did they forward improvement measures for its performance objective. Previous studies regarding the satisfaction of the university information disclosure system lacked the analysis of satisfaction levels according to the user's specific needs and purpose of use. Although user satisfaction was analyzed, the studies could not comprehensively analyze the user's level of performance perception nor could they posit improvement plans [5][6][7]. Therefore, the purpose of this study is to analyze the degree of satisfaction of the university information disclosure system and the degree of perception of performance outcomes recognized by university faculty and high school teachers [8]. Through this approach, we aim to identify concrete ways to improve performance targets, which cannot be achieved through a simple satisfaction survey.

\section{Research method}

(1) Research design

To analyze the satisfaction and perception of performance outcomes of the university information disclosure system, a representative user group was selected, and survey subjects were sampled among the selected user groups. The purpose of use of the university information disclosure system, satisfaction, and perception of performance was surveyed and the results were analyzed.

(2) Respondents

This study is centered on teachers, personnel currently employed at universities who perform tasks related to university information disclosure and university evaluation, and high school teachers who are responsible for college counselling [8]. Although the main target audience and users of the university information disclosure system are diverse, including students, parents, people involved in the sector, government, etc., only teachers and university officials were selected as research subjects.

The first reason is that teachers and university officials can represent the user information demand. Secondly, teachers and university officials have a higher frequency and experience of use than other user groups. This means not only do they have an understanding of the university information disclosure, its history, and changes, but there is a high possibility the purpose of use and level of satisfaction, and recognition of performance outcomes are relatively appropriate. Teachers can represent the information demands of high school students and parents. University officials can represent industries and government because they participate in the creation, provision, and use of information in the university information disclosure. However, if related research is conducted in the future, it is necessary to further subdivide the user groups. The surveyed teachers belong to the Student Admission Counseling Association (supported and operated by the South Korean government) and continuously use the university information disclosure to provide college counseling for students. The surveyed university officials oversee university information disclosure-related tasks at universities, continuously use the university information disclosure system. The 
university professors who participated in this study were in charge of administrative affairs at the university at the time of the survey or registered as evaluation committee members of Korea's university accreditation evaluation, so they know and use the contents of university information disclosure relatively well. The survey was completed by a total of 409 people: 132 university professors, 175 university staff, and 102 high school teachers [Table 1].

Table 1. Characteristics of survey respondents

\begin{tabular}{|c|c|c|c|}
\hline \multirow{4}{*}{ Target Group } & University Professor & $\mathrm{N}$ & $\%$ \\
\cline { 2 - 4 } & University Staff & 132 & 32.3 \\
\cline { 2 - 4 } & High School Teacher & 102 & 42.8 \\
\cline { 2 - 4 } & Total & 409 & 24.9 \\
\hline \multirow{3}{*}{ Gender } & Male & 313 & 100.0 \\
\cline { 2 - 4 } & Female & 96 & 76.5 \\
\hline \multirow{3}{*}{ Period of UIDS Use } & Less than 1 year & 28 & 23.5 \\
\cline { 2 - 4 } & Less than 2 years & 33 & 6.8 \\
\cline { 2 - 4 } & Less than 3 years & 68 & 8.1 \\
\cline { 2 - 4 } & Less than 4 years & 46 & 16.6 \\
\cline { 2 - 4 } & More than 5 years & 234 & 11.3 \\
& & & 57.2 \\
\hline
\end{tabular}

(3) Research instrument \& analysis method

The contents of the survey regarding the university information disclosure system were classified into: the purpose of use, satisfaction, and perception of performance outcomes [Table 2].

The survey items for use are 1) acquiring the information necessary for university admission: information on the university entrance screening process and information needed when selecting a university, 2) obtaining information on the status and performance of the university, and 3) obtaining information necessary for research and university evaluation. Respondents were allowed to select multiple items for use.

The satisfaction items were comprised of 1) satisfaction with the diversity of information (diversity of disclosure items) provided through university information disclosure, 2) satisfaction with the sufficiency of the information provided (degree of detail of the disclosure items provided), 3) satisfaction in the level of reliability of the information provided, and 4) satisfaction with the overall experience. For the satisfaction level, a Likert 5point scale was applied from very satisfied to very dissatisfied.

The items on the perception and recognition of the performance objectives of the university information disclosure were comprised of 1) guarantees the public's right to know, 2) expands the accountability of university education through public disclosure of university information, 3) provides appropriate information to information consumers, and 4) positive contribution towards selecting a university and program. A 5-point Likert scale was applied to gauge the level of perception for each item.

This study used basic statistical analysis to analyze the data of the survey. Descriptive statistics were conducted to analyze the relationship between the purpose of use, the perceived level of satisfaction, and the level of recognition of performance outcomes. 
Table 2. Survey items for the UIDS

\begin{tabular}{|c|c|c|c|c|}
\hline Category & Survey Item & Purpose of Use & Satisfaction & $\begin{array}{c}\text { Performance } \\
\text { Perception }\end{array}$ \\
\hline \multirow{3}{*}{ Purpose of Use } & Admissions Information Acquisition & $\circ$ & $\circ$ & \\
\hline & University Information Acquisition & ○ & ○ & \\
\hline & Use of Research and Evaluation & $\circ$ & ○ & \\
\hline \multirow{4}{*}{ Satisfaction } & Information Diversity & & o & \\
\hline & Information Sufficiency & & o & \\
\hline & Information Reliability & & o & \\
\hline & Overall Satisfaction & & o & \\
\hline \multirow{4}{*}{$\begin{array}{c}\text { Perception of } \\
\text { Performance } \\
\text { Outcomes }\end{array}$} & Fulfillment of the Right to Know & & & ० \\
\hline & $\begin{array}{c}\text { Enhances Accountability of University } \\
\text { Education }\end{array}$ & & & ○ \\
\hline & $\begin{array}{l}\text { Provides Appropriate Information to meet } \\
\text { Information Needs }\end{array}$ & & & $\circ$ \\
\hline & Selection of University and Program & & & 0 \\
\hline
\end{tabular}

\section{Analysis results}

\subsection{Analysis of purpose of use of UIDS}

The purpose of using the university information disclosure system is presented in [Table 3]. $64.3 \%$ of the respondents said they used the university information disclosure system to acquire 'university information', $61.3 \%$ used the university information disclosure system to acquire 'research and evaluation information', and 18.3\% answered their purpose of use was 'admissions information'. The relatively low level to gain admissions information can be attributed to the relatively low proportion of high school teachers and other consumers of information among the study's survey respondents.

Table 3. Purpose of use for UIDS

\begin{tabular}{|c|c|c|c|}
\hline Category & Number of Cases & $\begin{array}{c}\text { \%(Number of } \\
\text { Responses) }\end{array}$ & $\begin{array}{c}\text { \%(Number of } \\
\text { Respondents) }\end{array}$ \\
\hline Admissions Information & 73 & 12.7 & 18.3 \\
\hline University Information & 257 & 44.7 & 64.3 \\
\hline $\begin{array}{c}\text { Research and Evaluation } \\
\text { Information }\end{array}$ & 245 & 42.6 & 61.3 \\
\hline Total & 575 & 100.0 & 143.9 \\
\hline
\end{tabular}

\subsection{Analysis of satisfaction and perception of performance outcomes according to the purpose of use of the university information disclosure system}

[Table 4] shows the results of analyzing the satisfaction levels with the university information disclosure system according to each purpose of use. The user's overall satisfaction with the university information disclosure was 3.88 out of a total of 5 points. Satisfaction with the 'information reliability' was the highest at 4.07 , and satisfaction with 
'information diversity' was high at 4.01, but satisfaction with 'information sufficiency' was the lowest at 3.78.

By purpose of use, the overall satisfaction of the purpose of 'university information acquisition and research evaluation' was highest at 4.05, 'university information and research evaluation acquisition' was 3.97, 'admissions information acquisition' 3.90, 'research and evaluation information acquisition' at 3.88, 'university information acquisition' was 3.87, and 'admissions information and university information acquisition' was followed by 3.56. In particular, the satisfaction level of 'information sufficiency' to acquire university information and university information was the lowest at 3.50.

Table 4. Level of satisfaction \& perception of performance outcomes by the purpose of use of the UIDS

\begin{tabular}{|c|c|c|c|c|c|}
\hline \multicolumn{2}{|c|}{ Purpose of Use } & $\begin{array}{c}\text { Satisfaction in } \\
\text { Information } \\
\text { Diversity }\end{array}$ & $\begin{array}{c}\text { Satisfaction in } \\
\text { Information } \\
\text { Sufficiency }\end{array}$ & $\begin{array}{c}\text { Satisfaction in } \\
\text { Information } \\
\text { Reliability }\end{array}$ & $\begin{array}{c}\text { Overall } \\
\text { Satisfaction }\end{array}$ \\
\hline \multirow{2}{*}{$\begin{array}{c}\text { Admissions Information } \\
(\mathrm{N}=20)\end{array}$} & $\mathrm{M}$ & 4.05 & 4.05 & 3.95 & 3.90 \\
\cline { 2 - 6 } & $\mathrm{SD}$ & .826 & .826 & .999 & .968 \\
\hline $\begin{array}{c}\text { University Information } \\
(\mathrm{N}=103)\end{array}$ & $\mathrm{M}$ & 4.06 & 3.83 & 4.14 & 3.87 \\
\cline { 2 - 6 } & $\mathrm{SD}$ & .802 & .868 & .755 & .871 \\
\hline $\begin{array}{c}\text { Research \& Evaluation } \\
(\mathrm{N}=116)\end{array}$ & $\mathrm{M}$ & 3.98 & 3.73 & 4.08 & 3.88 \\
\cline { 2 - 6 } & $\mathrm{SD}$ & .813 & .817 & .759 & .846 \\
\hline $\begin{array}{c}\text { Admissions Information and } \\
\text { University Information } \\
(\mathrm{N}=34)\end{array}$ & $\mathrm{M}$ & 3.76 & 3.50 & 3.71 & 3.56 \\
\cline { 2 - 6 } & $\mathrm{SD}$ & .955 & 1.108 & .836 & .991 \\
\hline $\begin{array}{c}\text { University Information and } \\
\text { Research-Evaluation } \\
(\mathrm{N}=106)\end{array}$ & $\mathrm{M}$ & 4.08 & 3.86 & 4.08 & 3.97 \\
\cline { 2 - 6 } & $\mathrm{SD}$ & .757 & .786 & .719 & .762 \\
\hline $\begin{array}{c}\text { Admissions Information and } \\
\text { Research-Evaluation } \\
(\mathrm{N}=21)\end{array}$ & $\mathrm{M}$ & 3.90 & 3.71 & 4.38 & 4.05 \\
\cline { 2 - 6 } & $\mathrm{SD}$ & .831 & .784 & .590 & .740 \\
\hline $\begin{array}{c}\text { Total } \\
(\mathrm{N}=400)\end{array}$ & $\mathrm{M}$ & 4.01 & 3.78 & 4.07 & 3.88 \\
\cline { 2 - 6 } & $\mathrm{SD}$ & .810 & .852 & .767 & .848 \\
\hline
\end{tabular}

The results of analyzing users' perceptions of the performance outcomes of the university information disclosure system according to the purpose of use are shown in [Table 5]. The highest recognition of performance by the purpose of use was 'fulfillment of the right to know' which was 4.11 out of 5 points. The result of 'improving accountability' was 4.04, followed by 'providing appropriate data' at 3.84. The 'selection of university program' was the lowest at 3.59. When the university information disclosure was used to acquire 'admissions information', the rate of positive recognition was relatively high. On the other hand, the respondents' positive perception of outcome for 'admissions information and university information' was the lowest with less than 4 points amongst all four performance items. Therefore, it can be seen that in the case of users with various information needs for entering and applying to university, the perception of positive outcomes is relatively low. Also, except for 'acquisition of research and evaluation information' and 'fulfillment of the right to know', the remaining performance outcomes were shown to be below 4 points, indicating that there is a relatively high negative performance perception. In particular, the perception of the outcome of 'university program selection' is relatively low. The users that 
are not seeking 'admissions information' have the lowest positive performance perception, with an overall relatively low positive performance perception.

Table 5. Level of perception of performance outcomes by the purpose of use of UIDS

\begin{tabular}{|c|c|c|c|c|c|}
\hline \multicolumn{2}{|c}{} & $\begin{array}{c}\text { Fulfillment of } \\
\text { Right to } \\
\text { Know }\end{array}$ & $\begin{array}{c}\text { Increases } \\
\text { Accountability }\end{array}$ & $\begin{array}{c}\text { Availability of } \\
\text { Appropriate } \\
\text { Resources }\end{array}$ & $\begin{array}{c}\text { University } \\
\text { Program } \\
\text { Selection }\end{array}$ \\
\hline \multirow{2}{*}{$\begin{array}{c}\text { Admissions Information } \\
(\mathrm{N}=20)\end{array}$} & $\mathrm{M}$ & 4.15 & 4.15 & 3.95 & 4.05 \\
\cline { 2 - 6 } & $\mathrm{SD}$ & .875 & .813 & .945 & .887 \\
\hline $\begin{array}{c}\text { University Information } \\
(\mathrm{N}=103)\end{array}$ & $\mathrm{M}$ & 4.13 & 4.05 & 3.83 & 3.63 \\
\cline { 2 - 6 } & $\mathrm{SD}$ & .825 & .856 & .793 & .929 \\
\hline $\begin{array}{c}\text { Research \& Evaluation } \\
(\mathrm{N}=116)\end{array}$ & $\mathrm{M}$ & 4.06 & 3.97 & 3.74 & 3.34 \\
\cline { 2 - 6 } & $\mathrm{SD}$ & .805 & .823 & .924 & 1.005 \\
\hline \multirow{2}{*}{$\begin{array}{c}\text { Admissions Information and } \\
\text { University Information } \\
(\mathrm{N}=34)\end{array}$} & $\mathrm{M}$ & 3.82 & 3.74 & 3.62 & 3.74 \\
\cline { 2 - 6 } & $\mathrm{SD}$ & .834 & .828 & 1.015 & .790 \\
\hline $\begin{array}{c}\text { University Information and } \\
\text { Research- Evaluation } \\
(\mathrm{N}=106)\end{array}$ & $\mathrm{M}$ & 4.22 & 4.14 & 3.95 & 3.66 \\
\cline { 2 - 6 } & $\mathrm{SD}$ & .690 & .786 & .821 & .925 \\
\hline $\begin{array}{c}\text { Admissions Information and } \\
\text { Research-Reviews } \\
(\mathrm{N}=21)\end{array}$ & $\mathrm{M}$ & 4.24 & 4.19 & 4.10 & 3.76 \\
\cline { 2 - 6 } & $\mathrm{SD}$ & .700 & .750 & .831 & .995 \\
\hline $\begin{array}{c}\text { Total/Overall } \\
(\mathrm{N}=400)\end{array}$ & $\mathrm{M}$ & 4.11 & 4.04 & 3.84 & 3.59 \\
\cline { 2 - 6 } & $\mathrm{SD}$ & .785 & .822 & .873 & .953 \\
\hline
\end{tabular}

\section{Conclusion}

This study is a three-dimensional analysis of the current situation and strategies to improve the performance goals of the university information disclosure system. Unlike existing studies that sought to improve performance through user satisfaction analysis, this study comprehensively analyzed the user's purpose, satisfaction, and perception of the performance objectives. To improve the effectiveness and performance of university information disclosure, analysis of the characteristics of information demand and usage patterns by consumer groups and differentiation of related services are needed. Regarding performance outcomes, it was found necessary to improve and provide support for 'University and Program Selection'.

Despite the three-pronged approach, this study did not conduct a detailed analysis for each of the main characteristics of users. It is also limited by analyzing three dimensions only in a superficial way. Therefore, in future studies, it is necessary to analyze in greater depth the relationship between the main characteristics of users, the purpose of use, satisfaction, and the perception of performance outcomes.

University information disclosure is also carried out similarly in countries with developed higher education systems, such as the United States and the United Kingdom. By analyzing different contexts, strengths, and weaknesses through comparative research on the similarities and differences between each country's organizational goals, operation types, and disclosure items, it will be possible to explore strategies for improving the university information disclosure system of individual countries. In the case of South Korea, when the original purpose of disclosing university information was weighed against the pragmatic demands for enhancing the effectiveness of the government-funded project, many studies and analyses 
focused on the latter. It shows the phenomenon of negligence in achieving the original purpose of the project and improving performance.

With the development of new information and communication engineering technologies such as big data, machine learning, deep learning, and AI, the current university information disclosure system will undoubtedly change in the future. As technology advances, it is necessary to systematically analyze future international trends and the effects of these changes, to find predictions and response strategies for how the current university information disclosure system will change in the future.

\section{References}

[1] J.-Y. Park and J.-E. Chae, "A study on the university information disclosure system," The Journal of Law of Education, vol.18, no.1, pp.91-114, (2006)

[2] B.-J. Kim and S.-H. Choi, "Development tasks of university information disclosure system based on diagnosis on it," The Journal of Educational Administration, vol.31, no.4, pp.49-74, (2013)

[3] K.-H. Kim and K.-H. Lee, "A study on the improvement of university information disclosure system," The Journal of Korean Teacher Education, vol.28, no.2, pp.341-364, (2011)

[4] E.-J. Oh, "Analysis of information disclosure system of higher education," Asia-pacific Journal of Multimedia Services Convergent with Art, Humanities, and Sociology, vol.6, no.3, pp.363-372, (2016) DOI: 10.14257/AJMAHS.2016.03.41

[5] J.-H. Koo and C.-Y. Cho, "Analysis of university information disclosure services in the co-operative universities for operating the information disclosure system," Journal of the Korean Biblia Society for Library and Information Science, vol.29, no.2, pp.169-197, (2018) DOI:10.14699/kbiblia.2018.29.2.169

[6] J.-H. Yim and S.-Y. Woo, "Enhancement of universities' accountability mechanisms for freedom of information and disclosure," Journal of the Korean Society for Information Management, vol.26, no.1, pp.107-124, (2009) DOI:10.3743/KOSIM.2009.26.1.107

[7] J.-W. Ko and H.-S. Yu, "Analysis on higher education information disclosure system in the United States and its implications on Korea's higher education information policies," The Journal of Politics of Education, vol.17, no.4, pp.7-37, (2010)

[8] S.-Y. Lee and H.-S. Lee, "Analysis of factors influencing the satisfaction awareness of university information disclosure services," The Journal of Educational Research, vol.18, no.1, pp.67-86, (2020) DOI: 10.31352/JER.18.1.67 
An Analysis on the Satisfaction and Perception of Performance Outcomes of the University Information Disclosure System

This page is empty by intention. 